\title{
Managing Multiple Catchment Demands for Sustainable Water Use and Ecosystem Service Provision
}

\author{
Kathleen C. Stosch *, Richard S. Quilliam (D), Nils Bunnefeld and David M. Oliver \\ Biological \& Environmental Sciences, Faculty of Natural Sciences, University of Stirling, Stirling FK9 4LA, \\ Scotland, UK; richard.quilliam@stir.ac.uk (R.S.Q.); nils.bunnefeld@stir.ac.uk (N.B.); \\ david.oliver@stir.ac.uk (D.M.O.) \\ * Correspondence:kathleen.stosch@stir.ac.uk; Tel.: +44-178-646-7839
}

Received: 27 June 2017; Accepted: 23 August 2017; Published: 7 September 2017

\begin{abstract}
Ensuring water, food and energy security for a growing world population represents a 21st century catchment management challenge. Failure to recognise the complexity of interactions across ecosystem service provision can risk the loss of other key environmental and socioeconomic benefits from the natural capital of catchment systems. In particular, the ability of soil and water to meet human needs is undermined by uncertainties around climate change effects, ecosystem service interactions and conflicting stakeholder interests across catchments. This critical review draws from an extensive literature to discuss the benefits and challenges of utilising an ecosystem service approach for integrated catchment management (ICM). State-of-the-art research on ecosystem service assessment, mapping and participatory approaches is evaluated and a roadmap of the key short- and longer-term research needs for maximising landscape-scale ecosystem service provision from catchments is proposed.
\end{abstract}

Keywords: integrated catchment management; ecosystem service trade-offs and synergies; water-energy-food nexus; ecosystem service assessment; participatory research

\section{Introduction}

Catchments have been widely altered through large-scale land cover and land use change, including industrialisation, urbanisation, intensive agriculture and via hard-engineering, i.e., the construction of infrastructure designed to divert water for drinking, irrigation or hydropower schemes [1]. This has often benefitted economic productivity but has also frequently led to unintended consequences, such as reduced water quality and ecosystem functioning, and reduced resilience against other pressures such as invasive species and climate change [2]. Freshwater environments provide vital benefits to humans, and scientists and policy-makers increasingly look to ecosystem service theory and assessments to support sustainable catchment management. Ecosystem services are defined as the broad range of goods and services that an ecosystem provides, which enhance human health and wellbeing [3]. However, many of these services may be threatened where the upstream catchment system, within which a given waterbody is located, is poorly or inappropriately managed [4].

The recognition of catchments as a socio-ecological continuum that accommodates multiple interests of different stakeholders therefore offers a holistic framework within which to account for the breadth of ecosystem services that catchments host [5]. By assessing stakeholder interests across catchment functioning, from headwaters through to estuaries and bathing zones, we can begin to account for negative (trade-off) and positive (synergistic) interactions between ecosystem services that may arise from competing stakeholder interests [6]. Interactions and interdependencies between ecosystem services present a principal challenge for catchment management as it makes it difficult to 
predict the outcome of planning or mitigation options designed to tackle a particular environmental issue. Understanding such interactions is further complicated due to the spatial and temporal variability around natural processes, the occurrence of thresholds and 'tipping-points' in environmental systems, non-linearity and the potential for irreversible collapse of services in catchments $[7,8]$.

The interconnectedness of catchment attributes has long been recognised, and underpins the concept of integrated catchment management (ICM; [9]). ICM, similarly to integrated water resource management, is a holistic approach which considers the wider conflicts and synergies between management options and the objectives and responsibilities of stakeholder groups [10]. With unprecedented shifts in climate and land use change, and a rapidly changing political climate, it is essential that ICM evolves to balance competing demands for different ecosystem services across what has been coined the water-energy-food (WEF) nexus. WEF nexus thinking is an approach for integrated natural resource use which considers the interconnectivity between human resource use and the challenges of providing water, food and energy security for a growing global population [11]. WEF science represents an opportunity for truly interdisciplinary working and transformative research, which can benefit ICM and the ecosystem services approach to environmental management given the fertile, conceptual space that overlaps the disciplines of catchment science and ecological economics, ecological politics, remote sensing, and even computer game research. Arguably, the paradigm of ICM has become complacent with its acknowledgement of the need for interdisciplinary science rather than being fully exploited to deliver novel, cutting-edge interdisciplinary frameworks, i.e., practical outputs, to promote transformative catchment management, which allows the cooperation of multiple fields of research, stakeholder groups and quantifies trade-offs between management options within the WEF nexus, while considering wider ecosystem service provisioning. Thus, a more serious interdisciplinary research ambition needs to replace the superficial transdisciplinary rhetoric, such as at the economics and ecology interface [12]. There is a need, therefore, to quantify and optimise the range of multiple benefits that catchments can deliver in response to shifts in their management and the wider environment. Subsequently, the aims of this review areto: (i) define and critically review ecosystem trade-off research from a catchment perspective (Section 2); (ii) critically evaluate the benefits and challenges of utilising ecosystem service-based approaches for catchment management (Section 3); and (iii) propose a roadmap of future research to account for ecosystem trade-offs and co-benefits in decision-making and in turn promote more integrated catchment management (Section 4), supported by trans-disciplinary science. An extensive range of source material was identified, analysed, synthesised and evaluated for this review. The identification was conducted initially through a comprehensive web search of the major relevant concepts and topics using Web of Science and Google Scholar. A subsample of these contributions was selected based on the relevance of their titles initially, and their abstracts subsequently. Further contributions were selected by using a snowballing approach, which identified papers cited in reference lists but also determined subsequent publications that cited existing sources. The exception to this is Figure 2 which is based on the first author's data collection from an engagement exercise which captured the perception of 18 stakeholders (academics, environmental regulator staff, NGO staff and farmer's union staff) on ecosystem service provisioning in Scottish upland and lowland catchments at a research conference in Edinburgh in 2016.

\section{Ecosystem Service Trade-Offs and Co-Benefits from a Catchment Perspective}

Patterns of hydrological connectivity that generate the characteristic drainage network at the landscape scale are also responsible for the integration of water quality signatures from multiple stressors [13], for example, abstraction, hydrogeomorphological alterations, and diffuse and point sources of pollution [14]. Climate change impacts, and pressures to secure food, energy and water provision for nine billion people by 2050, combine to elevate and accelerate the magnitude of effects from such stressors in catchment systems. Understanding how different parts within the WEF nexus interact and how management decisions may affect ecosystem functioning and service provisioning is vital to manage catchments sustainably. This section defines and critically reviews ecosystem trade-off research from a catchment management perspective. 


\subsection{The Ecosystem Service Concept and Catchment Management}

The concept of ecosystem services is useful for catchment management because it provides a framework within which different functions and services of catchment systems can be recognised as part of a larger complex and interlinked landscape, and one where management options of one service may impact, positively or negatively, upon other services. Using the ecosystem service concept may hence aid cross-sectoral interaction and collaboration by highlighting the linkages between catchment management and ecosystem service provisioning, and by providing a common reference language which to help facilitate cooperation between stakeholder groups and research disciplines [15].

As part of the UN Millennium Ecosystem Assessment [3], ecosystem services were classified into three broad categories: provisioning (producing resources), regulatory (regulating processes in the natural environment), and culturally beneficial services. Supporting services sustain these three categories, and may be more appropriately named 'underlying ecosystem processes', as they do not directly benefit humans. While the ecosystem service concept has been criticised for being anthropocentric and capitalist [16], there are clear benefits of quantifying the services that the natural environment can provide, which would otherwise be undervalued. As a result, recent research has begun to map the spatial provision of ecosystem services across landscapes [17-19] and a number of approaches have taken the ecosystem services concept further in an effort to improve conservation and restoration projects and underpin other environmental decision-making [20-22], assess possible synergies and trade-offs between services $[6,23,24]$, or evaluate payment options for ecosystem services [25,26]. Multi-criteria modelling frameworks have also been developed to further provide decision-support on sustainable ecosystem service provision $[27,28]$. These can allow stakeholders to evaluate the outcomes of changes in land management and how they may affect wider ecosystem services.

\subsection{Trade-Offs between Ecosystem Services}

How people manage ecosystems for certain services will impact on the type, magnitude and relative composition of wider ecosystem service provision across catchment landscapes $[29,30]$. The interdependency of services presents a principal challenge for ecosystem and thus catchment management. Pair-wise interactions between ecosystem services can be thought of as either 'trade-off' or 'win-win' scenarios (Table 1); however, most ecosystem service interactions involve multiple provisioning, regulating and cultural ecosystem services. Interactions are further complicated as they usually involve many 'bundles' of ecosystem services which makes them highly difficult to predict. Bundles are groups of co-occurring, interacting ecosystem services that are provided from a certain area in the landscape [31]. A woodland, for instance, may provide timber and wild foods for foraging and hunting, carbon sequestration, pollutant and flood buffering, and recreational benefits [28]. When the woodland is degraded or its area is reduced, the entire bundle of services would also be reduced. The detailed illustrations and descriptions of ecosystem services in a European temperate grassland by Pilgrim et al. [32] show how complex ecosystem service interactions can be, even in a relatively simple and well-studied ecosystem.

Table 1. Examples of pair-wise trade-offs (negative interaction) and win-win (positive interaction) relationships between provisioning $(\mathrm{P})$ and regulating $(\mathrm{R})$ ecosystem services. Impacts may be expressed either locally, downstream, or in the wider environment.

\begin{tabular}{|c|c|c|c|c|c|}
\hline Driver & Service A & Service B & Scenario & Spatial Scale & Reference \\
\hline Forest harvesting & timber production $(\mathrm{P})$ & runoff, water quality (R) & trade-off & downstream & [34] \\
\hline Crop irrigation & crop production $(\mathrm{P})$ & soil salinisation (R) & trade-off & local & [36] \\
\hline $\begin{array}{l}\text { Diffuse pollution } \\
\text { buffer areas }\end{array}$ & water quality (R) & $\begin{array}{c}\text { soil, air \& groundwater } \\
\text { quality }(R)\end{array}$ & trade-off & $\begin{array}{c}\text { local, downstream } \\
\text { \& wider } \\
\text { environment }\end{array}$ & [37] \\
\hline
\end{tabular}


Table 1. Cont.

\begin{tabular}{cccccc}
\hline Driver & Service A & Service B & Scenario & Spatial Scale & Reference \\
\hline $\begin{array}{c}\text { Wetland } \\
\text { restoration }\end{array}$ & water quality (R) & fisheries $(\mathrm{P})$ & win-win & downstream & {$[24]$} \\
$\begin{array}{c}\text { Habitat } \\
\text { protection }\end{array}$ & pollination (R) & crop production $(\mathrm{P})$ & win-win & local & {$[39]$} \\
Lake restoration & water quality (R) & human health $(\mathrm{R})$ & win-win & downstream & {$[40]$} \\
Farmland forest & pest control (R) & coffee production $(\mathrm{P})$ & win-win & local & {$[41]$} \\
\hline
\end{tabular}

Trade-offs occur most often when an ecosystem is managed to increase or maintain a single service which causes the reduction of other services, or if services react to a common driver, such as land use change or climate change [6]. Humans have generally altered natural ecosystems (Figure 1a) to provide greater provisioning services, such as food production (Figure 1b); however, intensive management of catchments often significantly reduces regulating and cultural services which are not directly valued, such as carbon sequestration, river biodiversity, lake amenity values and human health [31].
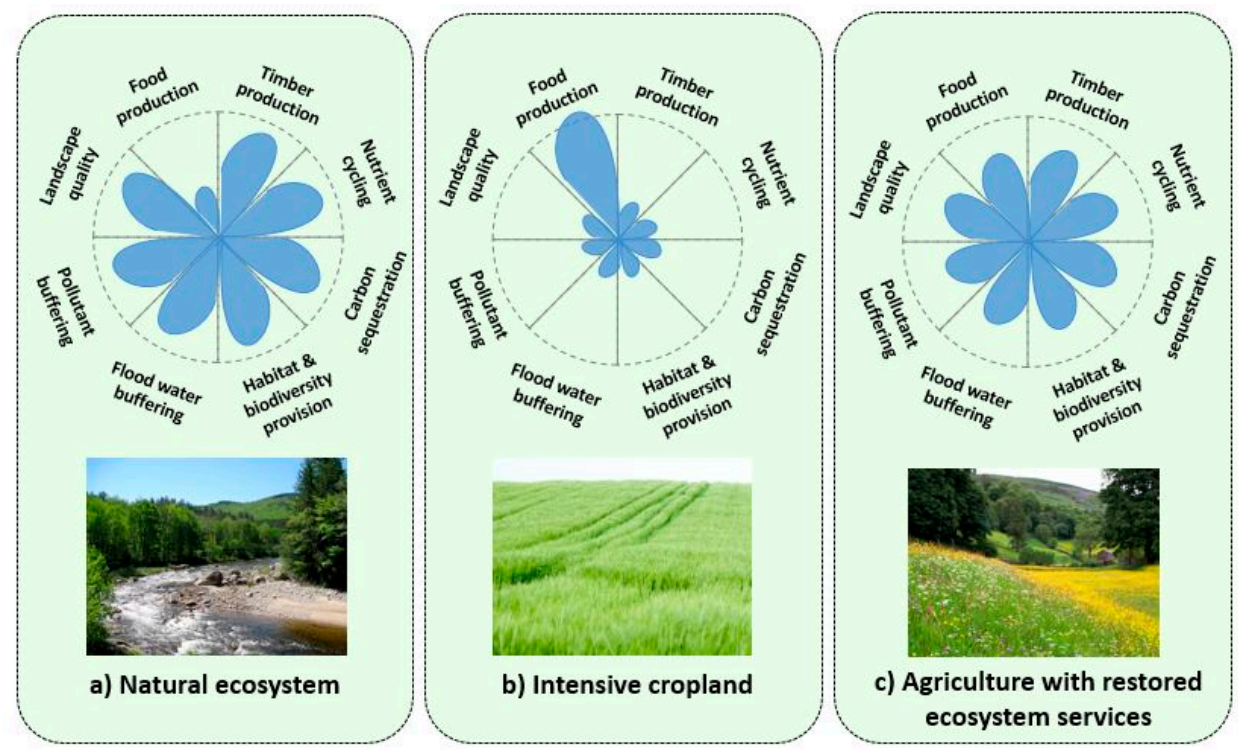

Figure 1. 'Flower diagrams' illustrating multiple ecosystem service provision under three hypothetical land uses, which are (a) natural; (b) intensively farmed and (c) managed for multiple ecosystem service provision. Ecosystem service provision is indicated along the axes, which are not labelled or normalised for this qualitative illustration. Adapted with permission from [Foley et al.], [Science], (2005), [42].

There are also examples of trade-offs between two regulating services, such as due to pollution swapping. Capturing diffuse pollutants in sedimentation ponds or buffer strips may reduce water pollution, but can increase soil, groundwater and air pollution ([37]; Table 1). Environmental externalities may compromise ecosystem functioning to such an extent that they compromise the targeted provisioning service itself. For example, irrigation-induced soil salinisation in the Murray-Darling Basin is estimated to cost Australia US\$200 million annually in lost agricultural production [36].

Trade-offs may be the result of an explicit management choice, but are often unintentional due to a lack of knowledge about ecosystem service interactions and the technical expertise to make decisions that benefit more than a single service. Even if a trade-off is intentional, there may be unwanted effects at different scales to those considered, especially at larger spatial and temporal scales [29]. Ecosystem service trade-offs may be classed along three axes depending on spatial scale, temporal scale and how reversible they are [29].

Temporal shortsightedness may be either predetermined or inadvertent, for example, as part of a political system, which works in short timescales of four to five years. An example of 
temporal externalities is the extraction of groundwater beyond replenishment rate, which may not yet significantly impact the current generation. Temporal trade-offs may also occur due to system lags and delays caused by hydrological and biogeochemical processes, meaning rivers may take decades to respond to reduced nutrient inputs to agricultural land $[43,44]$ and continue to be affected by so-called 'legacy' concentrations of pollutants, such as phosphorus. In some trade-offs, ecosystem function can be changed in such a way that it leads to regime shifts which may not be reversible [45], such as when a lake shifts to a eutrophic state, altering its chemical and biological makeup.

Ecosystem service trade-offs may be expressed at a local to a catchment or even global scale and ecosystem services are valued differently by stakeholders depending on the scale of interest [46]. An individual farmer's land is most profitable if it is entirely cultivated, however, riparian buffer strips may have a greater non-monetary ecosystem service provision on a catchment scale, which is why governments pay farm subsidies to allow some land to be taken out of production. Spatial trade-offs in catchments are often expressed downstream which means upstream users are less likely to experience negative effects, which then drives the potential for conflict between upstream and downstream users [47]. For example, there is a clear trade-off between the benefit of abstracting water upstream for a particular human use against the dis-benefits of reduced flows downstream, which may cause conflict between different communities or entire nations [48]. Some effects may be attenuated downstream due to pollutant and flood water buffering, however, if nutrient export and drainage are increased in the upper catchment, in-stream pollution and flooding are likely to increase for stakeholders in the lower catchment. Generally, upland catchments provide many key regulating ecosystem services, as lowland catchments are often more suited for agricultural production and human settlements (Figure 2).

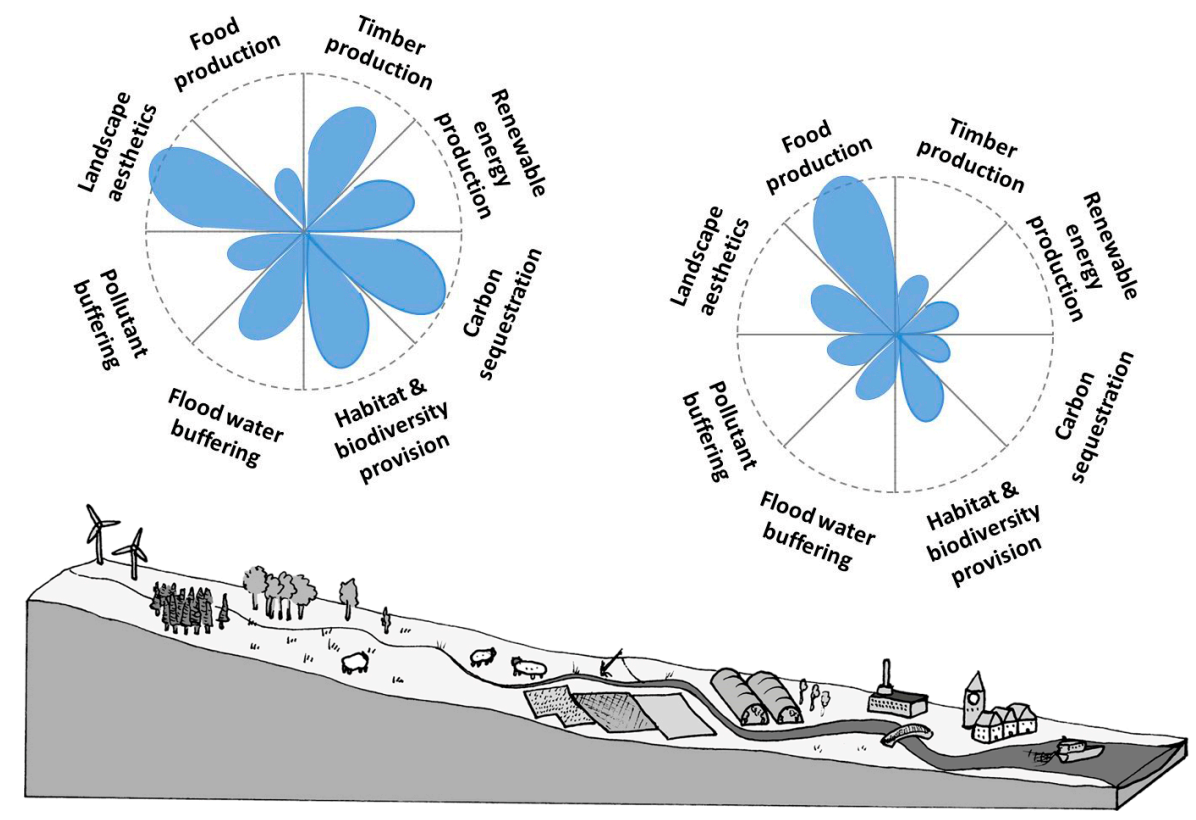

Figure 2. 'Flower diagrams' illustrating perceived multiple ecosystem service provision in an upper and lower catchment. Ecosystem service provision was indicated by stakeholders (academics $(n=9)$, environmental regulator staff $(n=5)$, NGO staff $(n=3)$ and farmer's union staff $(n=2))$ to estimate how they perceive provisioning in a generic Scottish upland and lowland catchment. Mean $( \pm$ SE) perceived ecosystem service provisioning (as a percentage of the total provisioning of the services in both parts of the catchment (total $=200 \%$ ) for the upper $(\mathrm{U})$ and lower $(\mathrm{L})$ catchment were: Food production: $\mathrm{U}=6.8 \pm 0.9, \mathrm{~L}=28.1 \pm 3.0$; Renewable energy production: $\mathrm{U}=12.6 \pm 1.7, \mathrm{~L}=6.3 \pm 1.3$; Timber production: $\mathrm{U}=19.5 \pm 1.9, \mathrm{~L}=7.0 \pm 1.4$; Carbon sequestration: $\mathrm{U}=24.8 \pm 3.0, \mathrm{~L}=5.7 \pm 0.8$; Habitat \& biodiversity provision: $\mathrm{U}=22.8 \pm 1.9, \mathrm{~L}=10.1 \pm 1.9$; Flood water buffering: $\mathrm{U}=17.8 \pm 1.9, \mathrm{~L}=8.0 \pm 1.3$; Pollutant buffering: $\mathrm{U}=8.7 \pm 1.8, \mathrm{~L}=7.2 \pm 1.2$; Landscape aesthetics: $\mathrm{U}=28.8 \pm 2.0, \mathrm{~L}=10.8 \pm 1.6$. 


\subsection{Win-Win Scenarios and Managing Catchments for Multiple Ecosystem Service Provision}

In contrast to trade-offs, 'win-win' situations occur when positively correlated services are enhanced concurrently through explicit management interventions. Land-based management options that limit nutrient loss from agricultural land, for instance, may save money for the farmer while also improving in-stream water quality, which in turn may benefit aquatic ecosystems and public health. Other management techniques, such as agricultural diversification and environmentally focused land management plans may benefit aquatic biodiversity without compromising farm incomes [49]. Trade-offs in ecosystem service are, however, more common than these synergistic relationships due to competing social, economic or ecological goals [23].Accounting for these competing factors may, however, allow interventions to be targeted at increasing the likelihood of win-win situations and the meeting of multiple demands.

Managing catchments for multiple ecosystem service provision may reduce the output of provisioning services significantly, but increase ecosystem functioning and human health and well-being overall (Figure 1c; [42]). Confronting the WEF challenges of the future, while preserving regulating and cultural ecosystem services, will require integrated management of those trade-offs driven by catchment governance, and a strategic move towards improved ecosystem service provision will be essential in order to underpin sustainable catchment management.

\subsection{Multiple Stakeholder Preferences within a Trade-Off}

Trade-offs may occur due to biophysical constraints within an ecosystem, but conflicts may also arise due to diverging preferences held by stakeholders [50]. The ecosystem service concept is socio-ecological and therefore not only depends upon the biogeophysical constraints of an ecosystem, but also on how people value the benefits and services that an ecosystem provides. When aiming to quantify and optimise ecosystem service provisioning in catchments one needs to be aware that different management scenarios may be not acceptable for people in certain parts of a catchment, or for certain stakeholder groups. Cavender-Bares et al. [51] developed an approach to integrate the biophysical and social trade-off between two services by balancing the preferences of stakeholders (illustrated in Figure 3). The production possibility frontier (PPF), shown as the black line in Figure 3, represents the balance between agricultural yield and downstream water quality in this example (Figure 3a). The shape of the PPF depends on the biogeophysical constraints of an ecosystem and can be changed through management practices and technology, for example, a catchment with very deep soils may be able to buffer excessive nutrient input, and therefore retain high water quality, in turn increasing crop yields. The curve may be moved upwards via the implementation of management options that increase both water quality and yield, e.g., through efficient fertiliser use, buffer zones or intercropping [33]. Isoclines of stakeholder utility values may also be plotted over the graph to model the preferences of stakeholder groups, with darker lines representing greater utility (Figure 3b). The point at which these meet the PPF represents the maximum sustainable utility value that a stakeholder may attain under these certain biophysical constraints of the PPF. Using these functions, the trade-off preferences of multiple stakeholders may be plotted, which shows the potential conflict between their positions (Figure 3c). This approach can thus reveal potential stakeholder conflict as each trajectory concomitantly increases utility for one stakeholder group, whilst decreasing it for the other. This subsequently provides insight into how valuable services are to different stakeholder groups, but more importantly also revealing potential sources of conflict and synergies between stakeholder groups. Using PPF and utility functions may reveal opportunities for win-win outcomes or identify whether stakeholders could be offered compensatory payments for utility losses [52]. This concept could also be used in catchment modelling to find minimum or optimum levels for certain ecosystem service provisioning or may simply be used as part of a participatory approach to engage stakeholders, allow discussion on barriers and conflicting preferences, and build shared mutual understanding to facilitate future cooperation. 


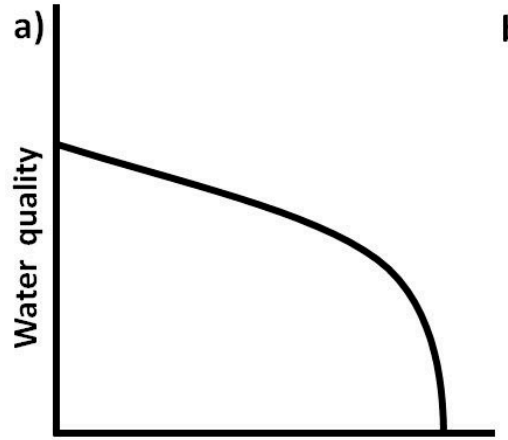

Agricultural yield

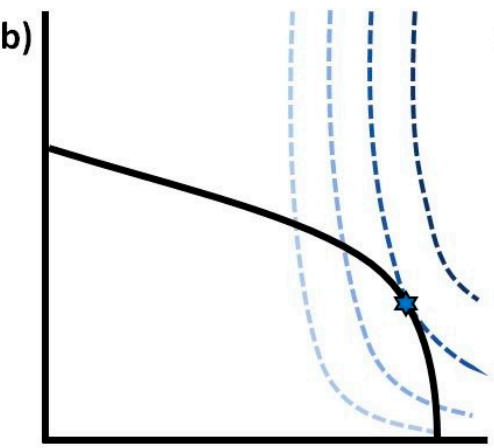

Agricultural yield

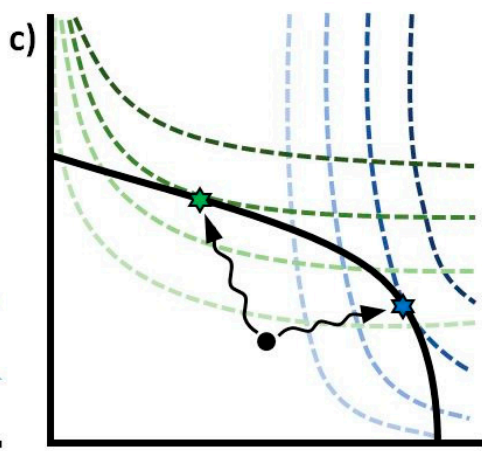

Agricultural yield

Figure 3. Illustrating the trade-off between water quality and agricultural yield using a production possibility frontier (PPF; black line, (a)), and the utility functions of two stakeholders with differing values (shades of green or blue dotted lines $(\mathbf{b})$ ). The blue star illustrates the ideal balance of the trade-off for upstream farmers, whereas the green star shows the preferences of downstream stakeholders, who are impacted by lowered water quality, such as people who use or manage downstream bathing waters (c). Reproduced from [King et al.], [Ecology and Society], (2015), [52].

\section{Using the Ecosystem Service Concept for Catchment Management}

In the 20th century, water managers relied on hard engineering solutions such as dams and centralised water treatment plants to meet human demands for water. As it became more apparent that past management of freshwater had degraded ecosystem functioning, there was increased realisation of alternative soft-path solutions [53,54]. Policy-makers and water companies increasingly recognised that catchment-based solutions, such as wetland restoration, may not only deliver multiple benefits for water quality improvements, flood buffering, carbon storage and habitat provision, but may be more cost-effective than engineering structures [55-57]. The following will critically review the benefits and challenges of utilising ecosystem service-based approaches for catchment management.

\subsection{Ecosystem Service-Based Approaches and Integrated Catchment Management (ICM)}

ICM recognises that to manage natural resources sustainably we need to understand how the different socio-ecological components of catchment ecosystems function and interact. The underpinning philosophy of the ICM process is to identify potential synergies and conflicts of different management options within an entire catchment and assess how they could remediate existing problems or those that may arise in the future. Integrated, ecosystem-based management, has so far been more widely utilised in marine ecosystem management [58-60], but has potential for catchment management due to the strong interactions between ecosystem services and the involvement of multiple stakeholders. These so-called ecosystem service-based management approaches should assess the delivery of ecosystem services and disservices, and aim to better understand ecosystem functioning and interdependencies while acknowledging uncertainties [61]. To achieve this, natural and social sciences need to be integrated to co-produce stakeholder-driven decision-making tools, which are both socio-ecologically sound and valuable to decision-makers, and align with emerging agendas in WEF nexus science. Stakeholder mapping tools can help identify the groups which may influence decision-making and those who may be impacted by it [62]. This approach allows water managers and decision-makers to consider how an entire socio-ecological system can function (including intangible services and less influential stakeholder groups), which can facilitate integrated catchment management, and in the long-term can help improve catchment functioning and service provision. However, while the value of adopting ICM and ecosystem service-based approaches is clear, their implementation can be challenging; they require significant resources to allow robust ecosystem service assessment and necessitate integration of stakeholder groups into the decision-making process along with representation of, and respect for, both natural and social perspectives. 


\subsection{Ecosystem Service Valuation Methods}

The ecological value of aquatic systems may be measured by indicators of its health state, such as biodiversity, water quality or combined indicators such as the EU Water Framework Directive's (WFD) ecological status [63]. Socio-economic values can be categorised as either 'use values' from consumptive goods, such as crops or timber, or non-consumptive 'non-use values', which can either be direct, such as landscape aesthetics or recreation, or indirect, such as nutrient cycling, erosion control or floodwater buffering [64]. Economists may estimate non-market values based on the cost of alternatives, such as installing a water treatment plant to replace natural water-purification services, or the cost of flooding to properties if a wetland has been removed [50,65-67]. For many ecosystem services, however, these revealed preference methods are not possible and valuation has to rely on stated preference from questionnaires, which makes it inherently difficult to accurately estimate non-market values, and there remain key gaps in knowledge around the value of ecosystem services. This is particularly true for cultural services, provisional services from genetic and medicinal resources, and regulating services such as seed dispersal and resistance to pests, pathogens and invasive species [68]. Furthermore, ecosystem service function may supply whole bundles of services that are often overlooked due to difficulties in their valuation. To value water quality related ecosystem services, for instance, a range of services need to be considered, such as drinking water treatment costs, human health benefits, and recreational opportunities [69]. There are also limitations to how accurately ecosystem services can be assessed, i.e., due to natural variability of services through time and space, and our lack of understanding of how ecosystem functioning supports ecosystem service provision [70]. Yet, exact valuations may not always be necessary, for example, if determining a management option with the greatest benefits for multiple ecosystem service provision [71].

The anthropocentric nature of the ecosystem service concept has led to a critique of ecosystem service valuation with suggestions that it may promote the 'commodification' of nature and lead to the degradation of parts of ecosystems which are not valued within ecosystem service assessments [72]. To counter that critique it is important to highlight that a number of natural resources are already valued via economic markets and so by valuing multiple ecosystem services it becomes possible to extend valuation beyond a few tangible services to those catchment resources that provide wider ecosystem functioning and human health benefits. Expressing the value of ecosystem services in monetary terms does help to raise awareness of the importance of ecosystems and biodiversity amongst the public and politicians, and enables more cost-efficient targeting of limited funds for protection and restoration [73]. It is necessary, however, to remain aware of the limitations of ecosystem service valuation if they are being used as part of ICM due to the difficulty of accurately valuing services. Even services which can be expressed in monetary terms may not be directly compared to other services and may be valued differently by particular stakeholders. If there is a disparity between service valuation of upstream and downstream catchment users payment systems may be set up to balance ecosystem service utility.

\subsection{Payment for Ecosystem Services (PES)}

The majority of ecosystem services from catchments, e.g., soil quality, may be classed as societal and cannot be paid for by the end-user. Many EU governments therefore intervene to stop the erosion of these services by investing in their protection, such as through agri-environment schemes [74]. A critique of current EU payment schemes is that they are not particularly well targeted to improve soil and water quality in catchments, but focus mainly on biodiversity and carbon sequestration [75]. Utilising user-financed 'payment for ecosystem services' (PES) schemes, where possible, can improve cost-effectiveness of catchment-scale management and can be locally targeted and monitored combining water quality and biodiversity [76,77]. Although PES is not a panacea that can address all environmental issues, it provides a useful tool that can be tailored to avoid the erosion of non-market ecosystem services and services with challenging spatial and temporal scales, and balance competing demands of upstream and downstream catchment users [78]. 
PES have potential to benefit ICM by incentivising management options that benefit the common good and improving downstream ecosystem services such as by buffering pollutants or flood water and helping decision-makers to recognise the value of the loss of wider ecosystem services catchments provide $[79,80]$. Another option for making PES schemes more effective is the development of spatially targeted decision support tools that take into account ecological, financial and social constraints of different management options and how they may impact on multiple ecosystem service provision [81].

\subsection{Ecosystem Service Assessment, Modelling and Mapping}

Over the past decade, research on ecosystem service assessment and mapping has increased substantially $[82,83]$. Due to their size and the spatial and temporal heterogeneity of ecosystems, tools such as geographic information systems (GIS) are regularly used for visualising and analysing landscape ecosystem service provision [84]. The scale and rationale for ecosystem service mapping studies varies greatly from large-scale global and continental studies, to catchment-scale investigations, identifying broader patterns of spatial ecosystem service distribution or researching more in-depth trade-off analyses, changes in ecosystem services, or the prioritisation of areas for planning and management $[31,68,85]$.

There are a growing number of approaches for ecosystem service mapping, e.g., spatial mapping can be informed via modelled outputs such as modelled nutrient runoff, or from direct measurements and observations, such as water quality $[84,86]$. Process-based models can offer a more dynamic (rather than static) assessment of ecosystem services under changing ecosystem variables and therefore can provide valuable decision support [84].Value transfer methodologies, which assign a total economic value to certain land cover types using GIS are also widely used for assessing ecosystem service provision (i.e., [87]). Different modelling tools may be applied for ecosystem service assessments in ICM, such as InVEST (Integrated Valuation of Ecosystem Service and Tradeoffs) mapping to estimate water yield and consumption for croplands in California [88], or the SWAT (Soil and Water Assessment Tool) to estimate stream flow, sediment yield, or surface runoff in catchments [89]. Ecosystem service mapping can be a powerful tool for ICM as it illustrates spatial trade-offs within a catchment and may help highlight potential synergies or conflicts of different management options.

\section{Challenges and Limitations of Ecosystem Service Assessments}

To make well-informed decisions about trade-offs between different management options, it is necessary to assess multiple ecosystem services at multiple scales, and to improve our knowledge of ecosystem service provision and valuation [64]. Most ecosystem service studies, however, focus on a small selection of services, and the more difficult to estimate cultural services are frequently omitted [18]. A large proportion of mapping studies lack sufficient scale-appropriate data, use secondary datamore frequently than raw data and do not validate their modelled results [18]. Seppelt et al. [90] concluded that less than a third of reviewed ecosystem service studies provided conclusions that were soundly based on science; and found that many studies lacked primary data, validation or quantitative assessment of uncertainties. Less than $40 \%$ of the reviewed ecosystem service studies make conclusions based on primary measurements or observations, most likely due to the expense and difficulty of collecting primary data [90]. Furthermore, most ecosystem service models fail to account for basic ecological concepts such as species interactions or Island Biogeography Theory [86]. Ecosystem services not only correspond to the ecological functioning of landscapes, but also to stakeholder's socio-economic and cultural value systems [50]. Due to these limitations of ecosystem service assessments to holistically capture the benefits that catchments provide, they may not be used to solely inform sustainable decision-making without the input of experts and local stakeholders.

Both environmental and socio-economic systems are complex and variable in space and time, which makes it inherently difficult to accurately model and map ecosystem services in catchments. There are uncertainties that arise from the inherent variability of the stochastic and often chaotic nature of natural phenomena, such as extreme weather events, and also from societal variability 
due to socio-economic and cultural dynamics, which can include chaotic and unpredictable drivers, e.g., wars and technological developments [91]. In addition, structural uncertainty in model design can arise due to a lack of understanding of the true biophysical processes that govern some complex environmental systems. When assessing the provision of ecosystem services, it is particularly important to be explicit about the uncertainties linked to our limited understanding of how ecosystem services are generated and how they may interact, particularly as many ecological quality indicators respond non-linearly to underlying pressures, and may display multiple stable states, thresholds, time lags, feedback loops or perhaps even irreversibility [8]. Efforts to restore rivers to WFD good status have shown that a trajectory towards reference states of water bodies may be impossible to achieve due to the dynamic nature of river systems [92]. Again, this limits the effectiveness of using static ecosystem mapping to inform catchment management. ICM requires outputs which reflect the range of outcomes that management options may have on ecosystem service delivery.

\subsection{Using Scenario Analysis}

Scenario analysis is such a tool that has great potential for ICM as it can use illustrate varying model states of a catchment. This may include accounting for possible temporal changes to policy and environmental drivers, and understanding how harder-to-predict, highly stochastic factors (e.g., world food market prices) can potentially affect future ecosystem service provision. There are a number of studies which combine trade-off analysis with scenario-based analyses such as determining the effects of changing policies, land cover or climate change [93-96]. Developing a number of land use scenarios using ecosystem service mapping tools may help inform policy-makers of potential trade-offs between different options for land use planning to improve catchment management [97].

Scenario analysis may also help account for the large variations between different stakeholder groups' views and preferences on catchment management and ecosystem service provisioning. Effective ICM requires input from local stakeholder groups to allow appropriate management that is based on local data, pressures and priorities, with further inputs from catchment scientists critical for ensuring that current understanding of catchment functioning is utilised.

\subsection{Participatory Approaches}

Participatory approaches to management of common resource pools are not a new concept [98]. However, in today's highly institutionalised top-down controlled social systems there is a need to relearn and reinvent bottom-up involvement to achieve more effective management of common resources and services, as conflicts may escalate when certain stakeholders are marginalised or ignored [99]. Priorities of stakeholder groups vary depending on local values and pressures [100], therefore policy-makers face the challenge of developing stakeholder-led, catchment-based approaches [101], which in turn can enable stakeholder groups to understand the pressures on their catchment system, assess their differing objectives and responsibilities, and help them consider possible synergies and conflicts of different management options. Involving stakeholders in decision-making throughout the planning process can make management options more inclusive, socially acceptable and maximise the likelihood of successful implementation of measures and strategies [102-104]. Participatory approaches can also enable the inclusion of services such as aesthetics or cultural values within ecosystem service assessments, which may not be quantified using spatial mapping. Finally, such approaches can help build social capacities of catchments to make communities more responsive, resilient and capable [105].

Some participatory approaches use mapping to enable stakeholder-driven weighted ratings of spatial ecosystem service provision, in turn highlighting important areas of special social and ecological importance which conventional service mapping cannot detect $[106,107]$. However, participatory approaches need to be underpinned by appropriate resources including sufficient time to explain methods, protocols and to build up stakeholder relationships, but when applied sensitively they can facilitate community-based catchment management by legitimising, analysing and representing 
local knowledge [108]. More influential stakeholders and institutions may not commit to this concept of full cooperation, and party politics and lobbying pressures may further impede bottom-up decision-making. A further challenge for stakeholder participation is that it takes time and money to build meaningful relationships with stakeholders, which is often limited by a three year research funding cycle [109]. Trust building ofan effective stakeholder group can take years to develop, and trust can also erode over time [110]. Although participatory approaches require significant time, resources and trust, they are a vital part for ICM and research can play a great role in developing engagement techniques which aid sustainable management of catchments.

\section{Recommendations for Future Research}

Addressing the significant global challenge of sustainable water and energy management while at the same time delivering food security for nine billion people by 2050 represents an exciting new frontier in catchment science [111,112]. This will not be achieved using a fragmented, piecemeal approach to catchment management. Instead, the lens of investigation needs to be focused to capture the entire catchment continuum and the complexity of environmental, ecological and social connectivity across the landscape. This requires the deployment of advanced environmental and social science tools grounded in fundamental and theoretical research to bridge traditional disciplinary boundaries, which can deliver strong applied and societal impact by maximising ecosystem service provision. This is driven, in part, by a policy and research landscape which increasingly recognises that water courses absorb pressures from their entire catchment area, and must therefore be managed more holistically toincrease benefits from catchment ecosystem services without compromising catchment functioning. Progress in this area has been evaluated in Sections 2-4, with significant developments in ICM and ecosystem service assessment noted. However, these concepts are still developing and have either not yet been put into practice, or matured sufficiently, to significantly improve sustainable management of catchments and their associated resources. A series of recommendations for future research are therefore proposed to help to promote effective ecosystem service provision via more integrated catchment management. The recommendations have been organised into a research agenda of short-term ( $0-5$ years) and long-term ( $>5-10$ years) opportunities.

\subsection{Short-Term Research Priorities (0-5 Years)}

Growing interest in WEF nexus science has led to a parallel increase in research to explore challenges and opportunities of managing trade-offs associated with decision-making within this critical nexus. Identifying the most pressing research questions needed to underpin WEF nexus science is therefore a clear priority, with co-designed research agendas beginning to emerge that combine viewpoints from researchers and business leaders in an effort to help companies manage their WEF nexus impacts [4]. Most research attention thus far has focussed on small-scale nexus interactions, such as $\mathrm{N}$ pollution from biofuel crops [113], rather than exploring more efficient ways of sustaining water, energy and food security. The WEF nexus agenda also provides strong rationale for energy and climate change policies to learn from the multiple and cumulative benefits that 'nexus-thinking' may deliver, particularly with respect to preserving freshwater ecosystems, such as wetland and floodplain restoration for carbon sequestration and water quality and biodiversity improvements, or energy generation from sewage [114].

\subsubsection{Transdisciplinary Research and Stakeholder Engagement}

The promotion of knowledge exchange mechanisms to foster more effective communication between scientists and decision-makers is becoming increasingly common in helping to tackle complex environmental challenges [115]. Catchment management has benefitted from recognition that such approaches help to build consensus and share wider perspectives to inform the decision-making process, but a more comprehensive understanding of the variability of viewpoints associated with decision-makers and beneficiaries of catchment management is needed, and across multiple spatial 
and temporal scales [116]. Innovation in stakeholder engagement methodologies will help to underpin this need for improved understanding as participatory research continues to evolve to take advantage of more engaging and mutually beneficial approaches such as participatory modelling and the co-production of knowledge [107,117]. More in-depth analysis of the characteristics of successful participatory modelling and research are clearly needed to help overcome the cultural, economic and technical constraints that can hinder effective engagement and participatory research. Participatory research should therefore focus on novel ways to exploit the benefits of social learning [26]. Wider deployment of structured engagement approaches should also be encouraged. For example, the citizen's jury technique is a useful approach to facilitate the combination of stakeholder and expert knowledge, which has already been successfully used in the context of catchment planning and risk management of microbial water pollution $[118,119]$. This technique has also been used to debate other contentious environmental issues, where it can provide a platform to facilitate social learning [120,121].

\subsubsection{Ecosystem Service Assessment and Decision-Making Frameworks}

To encourage the integration of stakeholders with catchment management decisions, existing ecosystem service assessment models and their outputs must be made more widely accessible. A particularly novel and interdisciplinary proposal is the 'gamification' of models and decision-support tools, made possible by the design of gaming interfaces as a user-friendly front-end to such tools, i.e., a graphic user interface. This would allow a large number of participants to 'play' and explore the underpinning science associated with the complexity of multiple impacts of decision-making which could, for example, allow a comparison of stakeholder accumulated trade-off preferences [122].

Exploiting ecosystem assessment studies to map wider arrays of ecosystem service provision in catchments is also a clear priority for the short-term future. These should aim to reflect the broad services that catchments provide, estimating multiple provisions in the WEF nexus as well as regulating services such as habitat and biodiversity provision, pollution and flood water buffering, and assess multiple improvements that management interventions may have on these. There is also a gap in researching the cultural services catchments provide to enhance people's wellbeing such as through landscape value, cultural heritage and recreational benefits. In doing so, a more comprehensive understanding of the likely interactions across ecosystem service provision should emerge, which in turn will help guide catchment management options that offer multiple benefits to wider society. Another important avenue of research is to understand how trade-offs and co-benefits spatially manifest themselves across terrestrial, freshwater and marine realms to assess potential synergies or conflict and inform sustainable management decisions [123].

Encouraging research to be more 'outcome driven' would offer advantages for the delivery of cost-effective environmental measures, which are likely to be implemented as part of integrated landscape management approaches, and capable of producing measurable benefits. Decision-making frameworks which incorporate 'outcome-oriented objective settings' can incorporate objectives such as maximising multiple ecosystem service provision or improving EU WFD ecological status as well as include socio-economic constraints, such as time, political context, governance and cost-effectiveness to select effective management options [124]. Such frameworks are likely to improve over time with more innovative integration of primary data, ecosystem service mapping, and expert elicitation to select management options for their greatest return on investment or to predict the outcomes of different options on service provision $[125,126]$. This would certainly help to guide future research designed to consider the potential outcomes of a portfolio of different catchment management actions, whether it focuses on improving a single ecosystem service or aims to maximise multiple ecosystem service provision.

Of the large number of decision-making tools developed for environmental management, few are actually used to inform policy [127-129]. This can be due to lack of confidence in the product, lack of ease of use, and due to the length of time it can take to embed a tool within an organisation that may ultimately use it. To prevent this 'implementation gap' there should hence be active 
engagement between providers and users throughout the development of any tool to maximise its utility, acceptability and speed of uptake [130]. Involving stakeholders in the design of a decision support tool for visualizing E. coli risk on agricultural land for instance, has helped to promote enthusiasm and understanding of the tool, and has enhanced its applicability [104].

More in-depth reporting of model methodology from ecosystem service assessment studies is essential, as clear information on specific modelling parameters and indicators is often unreliable or missing [90]. Furthermore, there have been calls for more defined methods and indicators for ecosystem service assessment to be made available to allow the reporting of consistent and comparable results [131]. Promoting a more coordinated strategy would enable the potential reuse of research outputs by improving the comparability of studies, perhaps with more effective outcomes with respect to real-world improvements in catchments. This may be a significant challenge for the research community however, as most researchers are likely to favour their own approaches and methodologies. More generally, reporting practices and standards need to be introduced for measuring ecological, socio-cultural and economic values to increase comparability and transferability [64].

Due to the lack of independent validation (inconsistencies among mapping approaches and little recognition of associated errors), land cover based proxy-maps can only ever be a crude estimation of spatial ecosystem service provision $[90,132,133]$. Eigenbrod et al. [134] first quantified the margin of error in land use based maps in the UK and showed that even good proxies could only show broad trends for ecosystem service provision, and were unsuitable to accurately show areas of multiple service provision or ecosystem service hotspots. Mapping must also communicate modelling uncertainty, as failing to incorporate this into mapping and decision-making may increase costs together with the likelihood of selecting unsuccessful management options [124]. Acknowledging and estimating uncertainty in ecosystem service prediction maps should be highly encouraged at the research funding stage to increase the quality of ecosystem assessment studies.

Uncertainty estimation should also be integrated into other ICM tools. Certainty weightings can be incorporated into expert elicitation methodologies [135], and setting upper and lower bounds on parameters can highlight best- and worst-case scenarios, rather than a single outcome. Bayesian Network models can present prediction uncertainties as probability distributions and such approaches have previously been used for ICM decision-support tools [136]. However, running uncertainty analyses for all subcomponents of an integrated model is extremely time-consuming [10]. Bayesian Networks can also be used to develop scenario-based analysis methods, which incorporate the likelihood of scenarios occurring, and reveal effects of continuous scenarios as opposed to a handful of discrete options [137]. Computational power is growing at a rapid rate, increasing the feasibility of uncertainty analysis in the future, which will allow models to explore spatial and temporal synergies and trade-offs and assess how ecosystem service provision vary in space and time. Models will, however, still be limited due to the uncertainties around our understanding of ecosystem services and how they interact.

\subsection{Long-Term Research Priorities (>5-10 Years)}

Institutional and structural barriers, such as a lack of commitment to ICM by decision-makers, limited time and resources, ineffective communication at the science-policy interface and poor internal collaboration need to be tackled to allow successful ICM. Research should aim for greater integration across political and scientific scales, such as integrating catchment and marine objectives [138], but also across national borders to facilitate the best possible outcomes [58]. There is also scope for more studies to integrate local stakeholders into the research process, from design to implementation, by co-producing ICM strategies. It will be a significant challenge to integrate land management policy at national scales, despite a recognition of the need for policies that deliver on a range of ecosystem services [101]. Indeed, in most countries, many of the management decisions around the WEF nexus and across terrestrial, freshwater and marine realms are highly fragmented and do not consider potential trade-offs or multiple benefits between services and realms. 
The existing evidence-base of published ecosystem assessment studies has a particular focus on the more developed nations of the world, with particular paucity of published research coming from Africa [19]. ICM linked to an ecosystem services framework would represent a significant research opportunity in less developed nations, especially as this would reduce their reliance on expensive engineering structures [4]. There is, however, a wealth of studies around PES schemes in developing countries (especially from Latin America), and there are exciting opportunities for the two-way exchange of results and research approaches from developing and developed countries [139]. Both Costa Rica and Mexico are, for example, developing additional financing sources from ecosystem service beneficiaries and are aiming for more targeted and differentiated payment schemes [77]. Adapting such approaches for EU agri-environment schemes may make these schemes more effective at improving ecosystem service provision, and be more cost-efficient. However, it is vitally important to incorporate the cultural and institutional differences into such method development, particularly when transferring PES approaches from countries with strongly developed legal frameworks to countries with a weak legal and institutional environment [139]. ES modelling and stakeholder engagement tools usually assume a stable government, infrastructure, available data and a willing and educated stakeholder pool. To successfully develop ICM in places with the greatest need will require a completely new approach, with the development of novel and innovative tools that work with local environmental, socio-economic and cultural constraints.

Finally, the longitudinal analysis of stakeholder perceptions, and how views might change, offers a particularly novel angle to the social science dimensions of catchment management. For example, the medical and health sciences often use cohort studies to track how different lifestyle choices can impact on health and wellbeing of the public, and in some cases such cohort studies can track results for extended periods, possibly decades. Transferring this concept to track temporal shifts in stakeholder and/or catchment citizen perceptions over time would be an interesting prospect. Participants of such a cohort study would presumably be exposed to and experience different 'catchment lives', which may impact on their perceptions and values of ecosystem service provision. The funding of such longitudinal study would clearly be challenging, especially given that longer timescales of tens of years would be of particular interest to monitor how shifts in cohort perceptions vary during their exposure to wider catchment understanding. Nonetheless, such a study would certainly represent frontier interdisciplinary research to better our understanding of the socio-ecological complexity of catchment systems.

\section{Conclusions}

Integrating complex stakeholder relationships and ecosystem service interactions into the process of ICM represents a significant challenge but also an exciting opportunity. The ecosystem service concept is useful to raise awareness among catchment managers and policy-makers of the need to maximise multiple ecosystem service provision, as opposed to selecting management options primarily to increase production of a few selected tangible services. Multidisciplinary and multi-stakeholder ecosystem service assessment can reveal hidden costs of managing an ecosystem simply for provisioning services, and help select management options for multiple ecosystem service provision to secure water, food and energy security while protecting the environment and human health and wellbeing. The practice of sustainable catchment management is now at a pivotal juncture where it faces the challenge of meeting an increasing amount of often competing demands on the services provided by catchment systems, but is also presented with a number of innovative and emerging research tools for deployment to begin to address that challenge. With careful assessment and continued efforts to deliver quality, cutting-edge research, the opportunities will outweigh the challenge.

Acknowledgments: The Scottish Government HydroNation Scholars Programme provided funding to support this work. 
Author Contributions: Kathleen C. Stosch carried out the literature review and drafted the article; David M. Oliver contributed substantially to writing the manuscript; Richard S. Quilliam and Nils Bunnefeld critically revised and supplemented the text.

Conflicts of Interest: The authors declare no conflict of interest.

\section{References}

1. Sterling, S.M.; Ducharne, A.; Polcher, J. The impact of global land-cover change on the terrestrial water cycle. Nat. Clim. Chang. 2012, 2, 1-6. [CrossRef]

2. Ormerod, S.J.; Dobson, M.; Hildrew, A.G.; Townsend, C.R. Multiple stressors in freshwater ecosystems. Freshw. Biol. 2010, 55, 1-4. [CrossRef]

3. Millenium Ecosystem Assessment. Ecosystems and Human Well-Being: Synthesis; Island Press: Washington, DC, USA, 2005; Volume 5, pp. 1-100. [CrossRef]

4. Green, P.A.; Vörösmarty, C.J.; Harrison, I.; Farrell, T.; Sáenz, L.; Fekete, B.M. Freshwater ecosystem services supporting humans: Pivoting from water crisis to water solutions. Glob. Environ. Chang. 2015, 34, 108-118. [CrossRef]

5. $\quad$ Likens, G.E.; Walker, K.F.; Davies, P.E.; Brookes, J.; Olley, J.; Young, W.J.; Thoms, M.C.; Lake, P.S.; Gawne, B.; Davis, J.; et al. Ecosystem science: Toward a new paradigm for managing Australia's inland aquatic ecosystems. Mar. Freshw. Res. 2009, 60, 271-279. [CrossRef]

6. Bennett, E.M.; Peterson, G.D.; Gordon, L.J. Understanding relationships among multiple ecosystem services. Ecol. Lett. 2009, 12, 1-11. [CrossRef] [PubMed]

7. Tromp-Van Meerveld, H.J.; McDonnell, J.J. Threshold relations in subsurface stormflow: 1. A 147-storm analysis of the Panola hillslope. Water Resour. Res. 2006, 42, 336. [CrossRef]

8. Spears, B.M.; Carvalho, L.; Perkins, R.; Kirika, A.; Paterson, D.M. Long-term variation and regulation of internal phosphorus loading in Loch Leven. Hydrobiologia 2012, 681, 23-33. [CrossRef]

9. Lerner, D.N.; Zheng, C. Integrated catchment management: Path to enlightenment. Hydrol. Process. 2011, 25, 2635-2640. [CrossRef]

10. Lerner, D.N.; Kumar, V.; Holzkämper, A.; Surridge, B.W.J.; Harris, B. Challenges in developing an integrated catchment management model. Water Environ. J. 2010, 25, 345-354. [CrossRef]

11. Biggs, E.M.; Bruce, E.; Boruff, B.; Duncan, J.M.A.; Horsley, J.; Pauli, N.; McNeill, K.; Neef, A.; Van Ogtrop, F.; Curnow, J.; et al. Sustainable development and the water-energy-food nexus: A perspective on livelihoods. Environ. Sci. Policy 2015, 54, 389-397. [CrossRef]

12. Spash, C.L. New foundations for ecological economics. Ecol. Econ. 2012, 77, 36-47. [CrossRef]

13. Heathwaite, A.L. Multiple stressors on water availability at global to catchment scales: Understanding human impact on nutrient cycles to protect water quality and water availability in the long term. Freshw. Biol. 2010, 55, 241-257. [CrossRef]

14. Elosegi, A.; Sabater, S. Effects of hydromorphological impacts on river ecosystem functioning: A review and suggestions for assessing ecological impacts. Hydrobiologia 2013, 712, 129-143. [CrossRef]

15. Galler, C.; Albert, C.; von Haaren, C. From regional environmental planning to implementation: Paths and challenges of integrating ecosystem services. Ecosyst. Serv. 2016, 18, 118-129. [CrossRef]

16. Gomez-Baggethun, E.; Ruiz-Perez, M. Economic valuation and the commodification of ecosystem services. Prog. Phys. Geogr. 2011, 35, 613-628. [CrossRef]

17. Landuyt, D.; Lemmens, P.; D’hondt, R.; Broekx, S.; Liekens, I.; De Bie, T.; Declerck, S.A.J.; De Meester, L.; Goethals, P.L.M. An ecosystem service approach to support integrated pond management: A case study using Bayesian belief networks-Highlighting opportunities and risks. J. Environ. Manag. 2014, 145, $79-87$. [CrossRef] [PubMed]

18. Martínez-Harms, M.J.; Balvanera, P. Methods for mapping ecosystem service supply: A review. Int. J. Biodivers. Sci. Ecosyst. Serv. Manag. 2012, 8, 17-25. [CrossRef]

19. De Araujo Barbosa, C.C.; Atkinson, P.M.; Dearing, J.A. Remote sensing of ecosystem services: A systematic review. Ecol. Indic. 2015, 52, 430-443. [CrossRef]

20. Fu, B.; Zhang, L.; Xu, Z.; Zhao, Y.; Wei, Y.; Skinner, D. Ecosystem services in changing land use. J. Soils Sediments 2015, 15, 833-843. [CrossRef] 
21. Trabucchi, M.; Ntshotsho, P.; Farrell, P.O.; Comín, F.A. Ecosystem service trends in basin-scale restoration initiatives: A review. J. Environ. Manag. 2012, 111, 18-23. [CrossRef] [PubMed]

22. Von Stackelberg, K.E. Decision analytic strategies for integrating ecosystem services and risk assessment. Integr. Environ. Assess. Manag. 2013, 9, 260-268. [CrossRef] [PubMed]

23. Howe, C.; Suich, H.; Vira, B.; Mace, G.M. Creating win-wins from trade-offs? Ecosystem services for human well-being: A meta-analysis of ecosystem service trade-offs and synergies in the real world. Glob. Environ. Chang. 2014, 28, 263-275. [CrossRef]

24. Butler, J.R.A.; Wong, G.Y.; Metcalfe, D.J.; Honzák, M.; Pert, P.L.; Rao, N.; van Grieken, M.E.; Lawson, T.; Bruce, C.; Kroon, F.J.; et al. An analysis of trade-offs between multiple ecosystem services and stakeholders linked to land use and water quality management in the Great Barrier Reef, Australia. Agric. Ecosyst. Environ. 2013, 180, 176-191. [CrossRef]

25. Derissen, S.; Latacz-Lohmann, U. What are PES? A review of definitions and an extension. Ecosyst. Serv. 2013, 6, 12-15. [CrossRef]

26. Matthies, B.D.; Kalliokoski, T.; Eyvindson, K.; Honkela, N.; Hukkinen, J.I.; Kuusinen, N.J.; Räisänen, P.; Valsta, L.T. Nudging service providers and assessing service trade-offs to reduce the social inefficiencies of payments for ecosystem services schemes. Environ. Sci. Policy 2016, 55, 228-237. [CrossRef]

27. Bohnet, I.C.; Roebeling, P.C.; Williams, K.J.; Holzworth, D.; van Grieken, M.E.; Pert, P.L.; Kroon, F.J.; Westcott, D.A.; Brodie, J. Landscapes Toolkit: An integrated modelling framework to assist stakeholders in exploring options for sustainable landscape development. Landsc. Ecol. 2011, 26, 1179-1198. [CrossRef]

28. Wam, H.K.; Bunnefeld, N.; Clarke, N.; Hofstad, O. Conflicting interests of ecosystem services: Multi-criteria modelling and indirect evaluation of trade-offs between monetary and non-monetary measures. Ecosyst. Serv. 2016, 22, 280-288. [CrossRef]

29. Rodríguez, J.P.; Beard, T.D.J.; Bennett, E.M.; Cumming, G.S.; Cork, S.J.; Agard, J.; Dobson, A.P.; Peterson, G.D. Trade-offs across space, time, and ecosystem services. Ecol. Soc. 2006, 11, 28. [CrossRef]

30. Cordingley, J.E.; Newton, A.C.; Rose, R.J.; Clarke, R.T.; Bullock, J.M. Can landscape-scale approaches to conservation management resolve biodiversity-ecosystem service trade-offs? J. Appl. Ecol. 2016, 53, 96-105. [CrossRef]

31. Raudsepp-Hearne, C.; Peterson, G.D.; Bennett, E.M. Ecosystem service bundles for analyzing tradeoffs in diverse landscapes. Proc. Natl. Acad. Sci. USA 2010, 107, 5242-5247. [CrossRef] [PubMed]

32. Pilgrim, E.S.; Macleod, C.J.A.; Blackwell, M.S.A.; Bol, R.; Hogan, D.V.; Chadwick, D.R.; Cardenas, L.; Misselbrook, T.H.; Haygarth, P.M.; Brazier, R.E.; et al. Interactions among agricultural production and other ecosystem services delivered from european temperate grassland systems. Adv. Agron. 2010, 109, 117-154.

33. Ewing, P.M.; Runck, B.C. Optimizing nitrogen rates in the midwestern United States for maximum ecosystem value. Ecol. Soc. 2015, 20. [CrossRef]

34. Costa, M.H.; Botta, A.; Cardille, J.A. Effects of large-scale changes in land cover on the discharge of the Tocantins River, Southeastern Amazonia. J. Hydrol. 2003, 283, 206-217. [CrossRef]

35. Engel, V.; Jobbágy, E.G.; Stieglitz, M.; Williams, M.; Jackson, R.B. Hydrological consequences of Eucalyptus afforestation in the Argentine Pampas. Water Resour. Res. 2005, 41, 3053-3057. [CrossRef]

36. Dehaan, R.L.; Taylor, G.R. Field-derived spectra of salinized soils and vegetation as indicators of irrigation-induced soil salinization. Remote Sens. Environ. 2002, 80, 406-417. [CrossRef]

37. Stevens, C.J.; Quinton, J.N.; Systems, A. Diffuse Pollution Swapping in Arable Agricultural Systems. Crit. Rev. Environ. Sci. Technol. 2009, 39, 478-520. [CrossRef]

38. Semeraro, T.; Giannuzzi, C.; Beccarisi, L.; Aretano, R.; De Marco, A.; Pasimeni, M.R.; Zurlini, G.; Petrosillo, I. A constructed treatment wetland as an opportunity to enhance biodiversity and ecosystem services. Ecol. Eng. 2015, 82, 517-526. [CrossRef]

39. Kasina, J.M.; Mburu, J.; Kraemer, M.; Holm-Mueller, K. Economic benefit of crop pollination by bees: A case of Kakamega small-holder farming in western Kenya. J. Econ. Entomol. 2009, 102, 467-473. [CrossRef] [PubMed]

40. Carvalho, L.; Mcdonald, C.; de Hoyos, C.; Mischke, U.; Phillips, G.; Borics, G.; Poikane, S.; Skjelbred, B.; Solheim, A.L.; Van Wichelen, J.; et al. Sustaining recreational quality of European lakes: Minimizing the health risks from algal blooms through phosphorus control. J. Appl. Ecol. 2013, 50, 315-323. [CrossRef]

41. Karp, D.S.; Mendenhall, C.D.; Sandí, R.F.; Chaumont, N.; Ehrlich, P.R.; Hadly, E.A.; Daily, G.C. Forest bolsters bird abundance, pest control and coffee yield. Ecol. Lett. 2013, 16, 1339-1347. [CrossRef] [PubMed] 
42. Foley, J.A.; Defries, R.; Asner, G.P.; Barford, C.; Bonan, G.; Carpenter, S.R.; Chapin, F.S.; Coe, M.T.; Daily, G.C.; Gibbs, H.K.; et al. Global consequences of land use. Science 2005, 309, 570-574. [CrossRef] [PubMed]

43. Hamilton, S.K. Biogeochemical time lags may delay responses of streams to ecological restoration. Freshw. Biol. 2012, 57, 43-57. [CrossRef]

44. Jarvie, H.P.; Sharpley, A.N.; Spears, B.; Buda, A.R.; May, L.; Kleinman, P.J.A. Water quality remediation faces unprecedented challenges from “legacy Phosphorus". Environ. Sci. Technol. 2013, 47, 8997-8998. [CrossRef] [PubMed]

45. Gordon, L.J.; Peterson, G.D.; Bennett, E.M. Agricultural modifications of hydrological flows create ecological surprises. Trends Ecol. Evol. 2008, 23, 211-219. [CrossRef] [PubMed]

46. Hein, L.; van Koppen, K.; de Groot, R.S.; van Ierland, E.C. Spatial scales, stakeholders and the valuation of ecosystem services. Ecol. Econ. 2006, 57, 209-228. [CrossRef]

47. Asquith, N.M.; Vargas, M.T.; Wunder, S. Selling two environmental services: In-kind payments for bird habitat and watershed protection in Los Negros, Bolivia. Ecol. Econ. 2008, 65, 675-684. [CrossRef]

48. Munia, H.; Guillaume, J.H.A.; Mirumachi, N.; Porkka, M.; Wada, Y.; Kummu, M. Water stress in global transboundary river basins: Significance of upstream water use on downstream stress. Environ. Res. Lett. 2016, 11, 14002. [CrossRef]

49. Stoeckl, N.; Chaiechi, T.; Farr, M.; Jarvis, D.; Álvarez-Romero, J.G.; Kennard, M.J.; Hermoso, V.; Pressey, R.L. Co-benefits and trade-offs between agriculture and conservation: A case study in Northern Australia. Biol. Conserv. 2015, 191, 478-494. [CrossRef]

50. Martin-Lopez, B.; Iniesta-Arandia, I.; Garcia-Llorente, M.; Palomo, I.; Casado-Arzuaga, I.; Garcia del Amo, D.; Gomez-Baggethun, E.; Oteros-Rozas, E.; Palacios-Agendez, I.; Willaarts, B.; et al. Uncovering ecosystem services bundles through social preferences. PLoS ONE 2012, 7, e38970. [CrossRef] [PubMed]

51. Cavender-Bares, J.; Polasky, S.; King, E.; Balvanera, P. A sustainability framework for assessing trade-offs in ecosystem services. Ecol. Soc. 2015, 20, 17. [CrossRef]

52. King, E.; Cavender-Bares, J.; Balvanera, P.; Mwampamba, T.H.; Polasky, S. Trade-offs in ecosystem services and varying stakeholder preferences: Evaluating conflicts, obstacles, and opportunities. Ecol. Soc. 2015, 20. [CrossRef]

53. Gleick, P.H. Global Freshwater Resources: Soft-Path Solutions for the 21st Century. Science 2003, 302, 1524-1528. [CrossRef] [PubMed]

54. Vörösmarty, C.J.; McIntyre, P.B.; Gessner, M.O.; Dudgeon, D.; Prusevich, A.; Green, P.; Glidden, S.; Bunn, S.E.; Sullivan, C.A.; Liermann, C.R.; et al. Global threats to human water security and river biodiversity. Nature 2010, 467, 555-561. [CrossRef] [PubMed]

55. Smith, L.E.D.; Porter, K.S. Management of catchments for the protection of water resources: Drawing on the New York City watershed experience. Reg. Environ. Chang. 2010, 10, 311-326. [CrossRef]

56. Ervin, B.D.; Brown, D.; Chang, H.; Dujon, V.; Granek, E.; Shandas, V.; Yeakley, A. Growing cities depend on ecosystem services. Solutions 2012, 2, 1-11.

57. Costanza, R.; de Groot, R.; Sutton, P.; van der Ploeg, S.; Anderson, S.J.; Kubiszewski, I.; Farber, S.; Turner, R.K. Changes in the global value of ecosystem services. Glob. Environ. Chang. 2014, 26, 152-158. [CrossRef]

58. Levin, N.; Tulloch, A.I.T.; Gordon, A.; Mazor, T.; Bunnefeld, N.; Kark, S. Incorporating Socioeconomic and Political Drivers of International Collaboration into Marine Conservation Planning. Bioscience 2013, 63, 547-563. [CrossRef]

59. Vasslides, J.M.; Jensen, O.P. Fuzzy cognitive mapping in support of integrated ecosystem assessments: Developing a shared conceptual model among stakeholders. J. Environ. Manag. 2016, 166, 348-356. [CrossRef] [PubMed]

60. Pendleton, L.; Mongruel, R.; Beaumont, N.; Hooper, T.; Charles, M. A triage approach to improve the relevance of marine ecosystem services assessments. Mar. Ecol. Prog. Ser. 2015, 530, 183-193. [CrossRef]

61. Martin-Ortega, J.; Jorda-Capdevila, D.; Glenk, K.; Holstead, K.L. What defines ecosystem services-based approaches? In Water Ecosystem Services: A Global Perspective; Martin-Ortega, J., Ferrier, R.C., Gordon, I.J., Khan, S., Eds.; Cambridge University Press: Cambridge, UK, 2015; pp. 3-13.

62. Sova, C.A.; Thornton, T.F.; Zougmore, R.; Helfgott, A.; Chaudhury, A.S. Power and influence mapping in Ghana's agricultural adaptation policy regime. Clim. Dev. 2016, 5529, 1-16. [CrossRef] 
63. Martinez-Haro, M.; Beiras, R.; Bellas, J.; Capela, R.; Coelho, J.P.; Lopes, I.; Moreira-Santos, M.; Reis-Henriques, A.M.; Ribeiro, R.; Santos, M.M.; et al. A review on the ecological quality status assessment in aquatic systems using community based indicators and ecotoxicological tools: What might be the added value of their combination? Ecol. Indic. 2015, 48, 8-16. [CrossRef]

64. De Groot, R.S.S.; Alkemade, R.; Braat, L.; Hein, L.; Willemen, L. Challenges in integrating the concept of ecosystem services and values in landscape planning, management and decision making. Ecol. Complex. 2010, 7, 260-272. [CrossRef]

65. Liu, S.; Costanza, R.; Farber, S.; Troy, A. Valuing ecosystem services Theory, practice, and the need for a transdisciplinary synthesis. Ann. N. Y. Acad. Sci. 2010, 1185, 54-78. [CrossRef] [PubMed]

66. Keeler, B.L.; Wood, S.A.; Polasky, S.; Kling, C.; Filstrup, C.T.; Downing, J.A. Recreational demand for clean water: Evidence from geotagged photographs by visitors to lakes. Front. Ecol. Environ. 2015, 13, 76-81. [CrossRef]

67. Liquete, C.; Maes, J.; La Notte, A.; Bidoglio, G. Securing water as a resource for society: An ecosystem services perspective. Ecohydrol. Hydrobiol. 2012, 11, 247-259. [CrossRef]

68. Harrison, P.A.; Vandewalle, M.; Sykes, M.T.; Berry, P.M.; Bugter, R.; de Bello, F.; Feld, C.K.; Grandin, U.; Harrington, R.; Haslett, J.R.; et al. Identifying and prioritising services in European terrestrial and freshwater ecosystems. Biodivers. Conserv. 2010, 19, 2791-2821. [CrossRef]

69. Keeler, B.L.; Polasky, S.; Brauman, K.A.; Johnson, K.A.; Finlay, J.C.; O’Neill, A.; Kovacs, K.; Dalzell, B. Linking water quality and well-being for improved assessment and valuation of ecosystem services. Proc. Natl. Acad. Sci. USA 2012, 109, 18619-18624. [CrossRef] [PubMed]

70. Hou, Y.; Burkhard, B.; Müller, F. Uncertainties in landscape analysis and ecosystem service assessment. J. Environ. Manag. 2013, 127, S117-S131. [CrossRef] [PubMed]

71. Gilvear, D.J.; Spray, C.J.; Casas-Mulet, R. River rehabilitation for the delivery of multiple ecosystem services at the river network scale. J. Environ. Manag. 2013, 126, 30-43. [CrossRef] [PubMed]

72. Kosoy, N.; Corbera, E. Payments for ecosystem services as commodity fetishism. Ecol. Econ. 2010, 69, 1228-1236. [CrossRef]

73. De Groot, R.; Brander, L.; van der Ploeg, S.; Costanza, R.; Bernard, F.; Braat, L.; Christie, M.; Crossman, N.; Ghermandi, A.; Hein, L.; et al. Global estimates of the value of ecosystems and their services in monetary units. Ecosyst. Serv. 2012, 1, 50-61. [CrossRef]

74. Honey-Rosés, J.; Acuña, V.; Bardina, M.; Brozović, N.; Marcé, R.; Munné, A.; Sabater, S.; Termes, M.; Valero, F.; Vega, À.; et al. Examining the Demand for Ecosystem Services: The Value of Stream Restoration for Drinking Water Treatment Managers in the Llobregat River, Spain. Ecol. Econ. 2013, 90, 196-205. [CrossRef]

75. Pe'er, G.; Dicks, L.V.; Visconti, P.; Arlettaz, R.; Báldi, A.; Benton, T.G.; Collins, S.; Dieterich, M.; Gregory, R.D.; Hartig, F.; et al. EU agricultural reform fails on biodiversity: Extra steps by member states are needed to protect farmed and grassland ecosystems. Science 2014, 344, 1090-1092. [CrossRef] [PubMed]

76. Ortega-Pacheco, D.V.; Lupi, F.; Kaplowitz, M.D. Payment for environmental services: Estimating demand within a tropical watershed. J. Nat. Resour. Policy Res. 2009, 1, 189-202. [CrossRef]

77. Wunder, S.; Engel, S.; Pagiola, S. Taking stock: A comparative analysis of payments for environmental services programs in developed and developing countries. Ecol. Econ. 2008, 65, 834-852. [CrossRef]

78. Engel, S.; Pagiola, S.; Wunder, S. Designing payments for environmental services in theory and practice: An overview of the issues. Ecol. Econ. 2008, 65, 663-674. [CrossRef]

79. Bellver-Domingo, A.; Hernández-Sancho, F.; Molinos-Senante, M. A review of Payment for Ecosystem Services for the economic internalization of environmental externalities: A water perspective. Geoforum 2016, 60, 115-118. [CrossRef]

80. Hack, J. Application of payments for hydrological ecosystem services to solve problems of fit and interplay in integrated water resources management. Water Int. 2015, 40, 929-948. [CrossRef]

81. Uthes, S.; Matzdorf, B. Studies on agri-environmental measures: A survey of the literature. Environ. Manag. 2013, 51, 251-266. [CrossRef] [PubMed]

82. Seppelt, R.; Fath, B.; Burkhard, B.; Fisher, J.L.; Grêt-Regamey, A.; Lautenbach, S.; Pert, P.; Hotes, S.; Spangenberg, J.; Verburg, P.H.; et al. Form follows function? Proposing a blueprint for ecosystem service assessments based on reviews and case studies. Ecol. Indic. 2012, 21, 145-154. [CrossRef]

83. Nelson, E.J.; Daily, G.C. Modelling ecosystem services in terrestrial systems. F1000 Biol. Rep. 2010, 2, 53. [CrossRef] [PubMed] 
84. Nemec, K.T.; Raudsepp-Hearne, C. The use of geographic information systems to map and assess ecosystem services. Biodivers. Conserv. 2013, 22, 1-15. [CrossRef]

85. Egoh, B.N.; Reyers, B.; Rouget, M.; Bode, M.; Richardson, D.M. Spatial congruence between biodiversity and ecosystem services in South Africa. Biol. Conserv. 2009, 142, 553-562. [CrossRef]

86. Maes, J.; Egoh, B.; Willemen, L.; Liquete, C.; Vihervaara, P.; Schägner, J.P.; Grizzetti, B.; Drakou, E.G.; La Notte, A.; Zulian, G.; et al. Mapping ecosystem services for policy support and decision making in the European Union. Ecosyst. Serv. 2012, 1, 31-39. [CrossRef]

87. Costanza, R.; Arge, R.; De Groot, R.; Farberk, S.; Grasso, M.; Hannon, B.; Limburg, K.; Naeem, S.; Neill, R.V.O.; Paruelo, J.; et al. The value of the world's ecosystem services and natural capital. Nature 1997, 387, 253-260. [CrossRef]

88. Matios, E.; Burney, J. Ecosystem Services Mapping for Sustainable Agricultural Water Management in California's Central Valley. Environ. Sci. Technol. 2017, 51, 2593-2601. [CrossRef] [PubMed]

89. Francesconi, W.; Srinivasan, R.; Perez-Miñana, E.; Willcock, S.P.; Quintero, M. Using the Soil and Water Assessment Tool (SWAT) to model ecosystem services: A systematic review. J. Hydrol. 2016, 535, 625-636. [CrossRef]

90. Seppelt, R.; Dormann, C.F.; Eppink, F.V.; Lautenbach, S.; Schmidt, S. A quantitative review of ecosystem service studies: Approaches, shortcomings and the road ahead. J. Appl. Ecol. 2011, 48, 630-636. [CrossRef]

91. Walker, W.E.; Harremoës, P.; Rotmans, J.; van der Sluijs, J.P.; van Asselt, M.B.; Janssen, P.; Krayer von Krauss, M.P. Defining uncertainty: A conceptual basis for uncertainty management in model-based decision support. Integr. Assess. 2003, 4, 5-17. [CrossRef]

92. Bouleau, G.; Pont, D. Did you say reference conditions? Ecological and socio-economic perspectives on the European Water Framework Directive. Environ. Sci. Policy 2015, 47, 32-41. [CrossRef]

93. Bateman, I.J.; Harwood, A.R.; Mace, G.M.; Watson, R.T.; Abson, D.J.; Andrews, B.; Binner, A.; Crowe, A.; Day, B.H.; Dugdale, S.; et al. Bringing ecosystem services into economic decision-making: Land use in the United Kingdom. Science 2013, 341, 45-50. [CrossRef] [PubMed]

94. Lawler, J.J.; Lewis, D.J.; Nelson, E.; Plantinga, A.J.; Polasky, S.; Withey, J.C.; Helmers, D.P.; Martinuzzi, S.; Pennington, D.; Radeloff, V.C. Projected land-use change impacts on ecosystem services in the United States. Proc. Natl. Acad. Sci. USA 2014, 111, 7492-7497. [CrossRef] [PubMed]

95. Nelson, E.; Polasky, S.; Lewis, D.J.; Plantinga, A.J.; Lonsdorf, E.; White, D.; Bael, D.; Lawler, J.J. Efficiency of incentives to jointly increase carbon sequestration and species conservation on a landscape. Proc. Natl. Acad. Sci. USA 2008, 105, 9471-9476. [CrossRef] [PubMed]

96. Kirchner, M.; Schmidt, J.; Kindermann, G.; Kulmer, V.; Mitter, H.; Prettenthaler, F.; Rüdisser, J.; Schauppenlehner, T.; Schönhart, M.; Strauss, F.; et al. Ecosystem services and economic development in Austrian agricultural landscapes-The impact of policy and climate change scenarios on trade-offs and synergies. Ecol. Econ. 2015, 109, 161-174. [CrossRef]

97. Zheng, H.; Li, Y.; Robinson, B.E.; Liu, G.; Ma, D.; Wang, F.; Lu, F.; Ouyang, Z.; Daily, G.C. Using ecosystem service trade-offs to inform water conservation policies and management practices. Front. Ecol. Environ. 2016, 14, 527-532. [CrossRef]

98. Ostrom, E. Governing the Commons: The Evolution of Institutions for Collective Action; Alt, J.E., North, D.C., Eds.; Cambridge University Press: Cambridge, UK, 1990.

99. Robbins, P. Political ecology: A critical introduction. In Critical Introductions to Geography; Wiley-Blackwell: Hoboken, NJ, USA, 2004; pp. 3-16, ISBN 1405102659.

100. Kaye-Zwiebel, E.; King, E. Kenyan pastoralist societies in transition: Varying perceptions of the value of ecosystem services. Ecol. Soc. 2014, 19, 17. [CrossRef]

101. McGonigle, D.F.; Harris, R.C.; McCamphill, C.; Kirk, S.; Dils, R.; MacDonald, J.; Bailey, S. Towards a more strategic approach to research to support catchment-based policy approaches to mitigate agricultural water pollution: A UK case-study. Environ. Sci. Policy 2012, 24, 4-14. [CrossRef]

102. Knight, A.T.; Cowling, R.M.; Campbell, B.M. An operational model for implementing conservation action. Conserv. Biol. 2006, 20, 408-419. [CrossRef] [PubMed]

103. Etienne, M.; du Toit, D.R.; Pollard, S. ARDI: A co-construction method for participatory modeling in natural resources management. Ecol. Soc. 2011, 16, 44. [CrossRef] 
104. Oliver, D.M.; Bartie, P.J.; Heathwaite, A.L.; Pschetz, L.; Quilliam, R.S. Design of a decision support tool for visualising E. coli risks on agricultural land using a stakeholder-driven approach. Land Use Policy 2017, 66, 227-234. [CrossRef]

105. Kuhlicke, C.; Steinführer, A.; Begg, C.; Bianchizza, C.; Bründl, M.; Buchecker, M.; De Marchi, B.; Di Masso Tarditti, M.; Höppner, C.; Komac, B.; et al. Perspectives on social capacity building for natural hazards: Outlining an emerging field of research and practice in Europe. Environ. Sci. Policy 2011, 14, 804-814. [CrossRef]

106. Bryan, B.A.; Raymond, C.M.; Crossman, N.D.; King, D. Comparing spatially explicit ecological and social values for natural areas to identify effective conservation strategies. Conserv. Biol. 2011, 25, 172-181. [CrossRef] [PubMed]

107. Mahboubi, P.; Parkes, M.; Stephen, C.; Chan, H.M. Using expert informed GIS to locate important marine social-ecological hotspots. J. Environ. Manag. 2015, 160, 342-352. [CrossRef] [PubMed]

108. Mccall, M.K.; Dunn, C.E. Geo-information tools for participatory spatial planning: Fulfilling the criteria for "good" governance? Geoforum 2012, 43, 81-94. [CrossRef]

109. Nancarrow, B.E. When the modeller meets the social scientist or vice-versa. In Proceedings of the MODSIM 2005 International Congress on Modelling and Simulation, Melbourne, Australia, 12-15 December 2005; pp. 38-44.

110. Menzel, S.; Buchecker, M. Does participatory planning foster the transformation toward more adaptive social-ecological systems? Ecol. Soc. 2013, 18, 265-267. [CrossRef]

111. Smith, P. Delivering food security without increasing pressure on land. Glob. Food Sec. 2013, 2, 18-23. [CrossRef]

112. Foley, J.A. Can we feed the world and sustain the planet? Sci. Am. 2011, 305, 60-65. [CrossRef] [PubMed]

113. Donner, S.D.; Kucharik, C.J. Corn-based ethanol production compromises goal of reducing nitrogen export by the Mississippi River. Proc. Natl. Acad. Sci. USA 2008, 105, 4513-4518. [CrossRef] [PubMed]

114. Pittock, J. National climate change policies and sustainable water management: Conflicts and synergies. Ecol. Soc. 2011, 16, 25. [CrossRef]

115. Karpouzoglou, T.; Dewulf, A.; Clark, J. Advancing adaptive governance of social-ecological systems through theoretical multiplicity. Environ. Sci. Policy 2016, 57, 1-9. [CrossRef]

116. Austin, Z.; McVittie, A.; McCracken, D.; Moxey, A.; Moran, D.; White, P.C.L. The co-benefits of biodiversity conservation programmes on wider ecosystem services. Ecosyst. Serv. 2016, 20, 37-43. [CrossRef]

117. Whitman, G.P.; Pain, R.; Milledge, D.G. Going with the flow? Using participatory action research in physical geography. Progress Phys. Geogr. 2015, 39, 1-18. [CrossRef]

118. Huitema, D.; Cornelisse, C.; Ottow, B. Is the jury still out? toward greater insight in policy learning in participatory decision processes-The case of dutch citizens' juries on water management in the rhine basin. Ecol. Soc. 2010, 15, 16. [CrossRef]

119. Fish, R.D.; Winter, M.; Oliver, D.M.; Chadwick, D.R.; Hodgson, C.J.; Heathwaite, A.L. Employing the citizens' jury technique to elicit reasoned public judgments about environmental risk: Insights from an inquiry into the governance of microbial water pollution. J. Environ. Plan. Manag. 2013, 57, 233-253. [CrossRef]

120. Petts, J. Evaluating the effectiveness of deliberative processes: Waste management case-studies. J. Environ. Plan. Manag. 2001, 44, 207-226. [CrossRef]

121. Kenyon, W.; Nevin, C.; Hanley, N. Enhancing environmental decision-making using citizens' juries. Local Environ. 2003, 8, 221-232. [CrossRef]

122. Turner, K.G.; Anderson, S.; Gonzales-Chang, M.; Costanza, R.; Courville, S.; Dalgaard, T.; Dominati, E.; Kubiszewski, I.; Ogilvy, S.; Porfirio, L.; et al. A review of methods, data, and models to assess changes in the value of ecosystem services from land degradation and restoration. Ecol. Model. 2016, 319, 190-207. [CrossRef]

123. Adams, V.M.; Álvarez-Romero, J.G.; Carwardine, J.; Cattarino, L.; Hermoso, V.; Kennard, M.J.; Linke, S.; Pressey, R.L.; Stoeckl, N. Planning across freshwater and terrestrial realms: Cobenefits and tradeoffs between conservation actions. Conserv. Lett. 2014, 7, 425-440. [CrossRef]

124. Tulloch, V.J.D.; Tulloch, A.I.T.; Visconti, P.; Halpern, B.S.; Watson, J.E.M.; Evans, M.C.; Auerbach, N.A.; Barnes, M.; Beger, M.; Chadès, I.; et al. Why do we map threats? Linking threat mapping with actions to make better conservation decisions. Front. Ecol. Environ. 2015, 13, 91-99. [CrossRef] 
125. Joseph, L.N.; Maloney, R.F.; Possingham, H.P. Optimal allocation of resources among threatened species: A project prioritization protocol. Conserv. Biol. 2009, 23, 328-338. [CrossRef] [PubMed]

126. Withey, J.C.; Lawler, J.J.; Polasky, S.; Plantinga, A.J.; Nelson, E.J.; Kareiva, P.; Wilsey, C.B.; Schloss, C.A.; Nogeire, T.M.; Ruesch, A.; et al. Maximising return on conservation investment in the conterminous USA. Ecol. Lett. 2012, 15, 1249-1256. [CrossRef] [PubMed]

127. Borowski, I.; Hare, M. Exploring the gap between water managers and researchers: Difficulties of model-based tools to support practical water management. Water Resour. Manag. 2007, 21, 1049-1074. [CrossRef]

128. Dan Delden, H.; Seppelt, R.; White, R.; Jakeman, A.J. A methodology for the design and development of integrated models for policy support. Environ. Model. Softw. 2011, 26, 266-279. [CrossRef]

129. Bunnefeld, N.; Milner-Gulland, E.; Nicholson, E. Decision-Making in Conservation and Natural Resource Management: Models for Interdisciplinary Approaches; Forthcoming 2017 in Cambridge University Press.

130. Oliver, D.M.; Fish, R.D.; Winter, M.; Hodgson, C.J.; Heathwaite, A.L.; Chadwick, D.R. Valuing local knowledge as a source of expert data: Farmer engagement and the design of decision support systems. Environ. Model. Softw. 2012, 36, 76-85. [CrossRef]

131. Lamarque, P.; Quétier, F.; Lavorel, S. The diversity of the ecosystem services concept and its implications for their assessment and management. Comptes Rendus Biol. 2011, 334, 441-449. [CrossRef] [PubMed]

132. Egoh, B.; Rouget, M.; Reyers, B.; Knight, A.T.; Cowling, R.M.; van Jaarsveld, A.S.; Welz, A. Integrating ecosystem services into conservation assessments: A review. Ecol. Econ. 2007, 63, 714-721. [CrossRef]

133. Schulp, C.J.E.; Burkhard, B.; Maes, J.; Van Vliet, J.; Verburg, P.H. Uncertainties in Ecosystem Service Maps: A Comparison on the European Scale. PLoS ONE 2014, 9, e109643. [CrossRef] [PubMed]

134. Eigenbrod, F.; Armsworth, P.R.; Anderson, B.J.; Heinemeyer, A.; Gillings, S.; Roy, D.B.; Thomas, C.D.; Gaston, K.J. The impact of proxy-based methods on mapping the distribution of ecosystem services. J. Appl. Ecol. 2010, 47, 377-385. [CrossRef]

135. Page, T.; Heathwaite, A.L.; Thompson, L.J.; Pope, L.; Willows, R. Environmental Modelling \& Software Eliciting fuzzy distributions from experts for ranking conceptual risk model components. Environ. Model. Softw. 2012, 36, 19-34. [CrossRef]

136. Holzkämper, A.; Kumar, V.; Surridge, B.W.J.; Paetzold, A.; Lerner, D.N. Bringing diverse knowledge sources together-A meta-model for supporting integrated catchment management. J. Environ. Manag. 2012, 96, 116-127. [CrossRef] [PubMed]

137. Dong, C.; Schoups, G.; van de Giesen, N. Scenario development for decision-making in water resources planning and management: A review. Technol. Forecast. Soc. Chang. 2012, 2, 928-931. [CrossRef]

138. Álvarez-romero, J.G.; Adams, V.M.; Pressey, R.L.; Douglas, M.; Dale, A.P.; Augé, A.A.; Ball, D.; Childs, J.; Digby, M.; Dobbs, R.; et al. Integrated cross-realm planning: A decision-makers ' perspective. Biol. Conserv. 2015, 191, 799-808. [CrossRef]

139. Schomers, S.; Matzdorf, B. Payments for ecosystem services: A review and comparison of developing and industrialized countries. Ecosyst. Serv. 2013, 6, 16-30. [CrossRef]

(C) 2017 by the authors. Licensee MDPI, Basel, Switzerland. This article is an open access article distributed under the terms and conditions of the Creative Commons Attribution (CC BY) license (http:/ / creativecommons.org/licenses/by/4.0/). 